\title{
The Effect of Range Of Motion (ROM) Exercise on the Level of Stroke Patient Mobility
}

\author{
Muriyati ${ }^{*}$, Safruddin'2,Andi Nurwahyuni Asmur ${ }^{3}$ \\ Departemen Surgical and Medical Nursing Stikes Panrita Husada Bulukumba, Indonesia ${ }^{1}$ \\ Departemen Community and Family Nursing, Stikes Panrita Husada Bulukumba ,Indonesia ${ }^{2}$ \\ S1 Nursing Study Program, Stikes Panrita Husada Bulukumba, Indonesia ${ }^{3}$
}

Corresponding Autor: Muriyati.stikes@gmail.com ${ }^{*}$

\begin{abstract}
One form of mobilization that can be given is by doing ROM exercises. Muscle strength in stroke patients can be done immediately through ROM exercises after a stroke has passed. The impact of ROM exercises that are not immediately performed in stroke patients as early as possible is the occurrence of muscle cell atrophy, joint stiffness, decreased muscle contraction, pain during movement and as a whole will result in the inability to move or activity. The purpose of this study is to investigate the effect of Range Of Exercise Motion (ROM) Against the Level of Mobility of Stroke Patients in the Seruni and Flamboyant Treatment Room of H. Andi Sulthan Hospital, Daeng Radja Bulukumba. This type of research is quantitative research, this type of research uses pre-experimental research, with one group research design pre and posttest design. The sample of this study were 30 respondents taken by purposive sampling method. Data analysis in this study used a statistical test dependent test (paired-sample t-test). The results of the analysis used a paired sample t-test with a level of confidence $(\alpha=0.05)$. Based on the results of this test, the $p$-value is 0.007 , thus $p<\alpha(0.007<0.05)$, then Ha is accepted. This study concludes that there is the effect of Range of Motion (ROM) Exercise on the Mobility Level of Stroke Patients in the Seruni and Flamboyant Treatment Room of H. Andi Sulthan Daeng Radja Bulukumba Hospital. Suggestion: It is expected to be able to add information and input for health workers to improve the quality of health services provided and is expected to also provide benefits to the public in terms of information about the importance of the range of motion (ROM) training on the level of mobility of stroke patients
\end{abstract}

\section{Keywords: Range of Motion, Exercise, Mobility, Stroke}

\section{INTRODUCTION}

Stroke is a clinical syndrome due to brain blood vessel disorders, which arise suddenly and usually affects patients aged 45-80 years. Generally, men are slightly more often affected than women. Usually, there are no early symptoms, and they appear so suddenly. The cause of stroke, as revealed by Smeltzer, results from one of four events: thrombosis, cerebral embolism, ischemia, and cerebral hemorrhage. Other causes of stroke are less common such as congenital defects in blood vessel walls or abnormalities in the blood clotting system (Artati, 2013). Clinically the symptoms that 
often appear are attacks of neurological deficits / focal paralysis such as hemiparesis, ie paralysis of the right or left side of the body only, then talk to be pelo or speech is not very clear, difficulty walking and loss of balance. The problem that often arises in stroke patients is a movement disorder, the patient experiences a disturbance or difficulty when walking due to a disturbance in muscle strength and body balance (Mahardika, 2016).

Stroke patients who experience weakness on one side of the body are caused by a decrease in muscle tone, so they are unable to move their body (immobilization). Immobilization that does not get proper treatment will cause complications in the form of tone abnormalities, orthostatic hypotension, deep vein thrombosis and contractures (Murtaqib, 2013). One form of early rehabilitation in stroke patients is to provide mobilization. Early mobilization may also reduce all bed-related complications such as pneumonia, Deep Vein Thrombosis (DVT), pulmonary embolism, pressure sores, and orthostatic blood pressure problems. Early mobilization may also have important psychological effects (Artati, 2013). Someone who has movement disorders or interference with muscle strength will have an impact on their daily activities. To prevent complications from other diseases it is necessary to do mobilization exercises. Mobilization is a person's ability to move freely, easily, and regularly which aims to meet the needs of a healthy life. Mobilization is needed to improve self-independence, improve health, slow the process of disease, especially degenerative diseases and for self-actualization (self-esteem and body image) (Purwanti \& Purwaningsih, 2013).

Prevention and appropriate treatment in stroke patients is very important. Stroke that does not get good handling will cause various levels of disturbance, such as decreased muscle tone, loss of sensibility in some parts of the body, decreased ability to move diseased limbs and inability to perform certain activities. Stroke patients who experience weakness on one side of the body are caused by a decrease in muscle tone, so they are unable to move their body (immobilization). Immobilization that does not get proper treatment will cause complications in the form of tone abnormalities, orthostatic hypotension, deep vein thrombosis and contractures. Muscle atrophy due to lack of activity can occur only in less than one month after a stroke (Murtaqib, 2013). Stroke sufferers must be mobilized as early as possible when the neurological and hemodynamic clinical conditions of the patient have begun to stabilize. Mobilization is done routinely and continuously to prevent stroke complications, especially 
contractures. Mobilization in stroke patients aims to maintain the range of motion (ROM) to improve respiratory function, circulatory circulation, prevent complications and maximize self-care activities (Murtaqib, 2013).

One form of mobilization that can be given is by doing ROM exercises. Muscle strength in stroke patients can be done immediately through ROM exercises after a stroke has passed. The impact of ROM exercises that are not immediately carried out in stroke patients as early as possible is the occurrence of muscle cell atrophy, joint stiffness, decreased muscle contraction, pain during movement and overall will result in the inability to move or activity (Murtaqib, 2013). Existing research shows that very early mobilization is one of the key factors in the care of stroke patients (Mahardika, 2016). Based on the research of Yuni (2013), there is an influence of giving early mobilization in infarction stroke to increase functional recovery. The results of this study recommend that nurses provide the application of early mobilization to hemorrhagic stroke patients who are hospitalized so that the patient's functional ability increases. Based on WHO data (2013) every year there are 15 million people around the world suffer a stroke. Among them found the number of deaths of 5 million people and 5 million others experienced permanent disability. According to Basic Health Research / Riskesdas (2013) data, the prevalence of stroke in Indonesia is 12.1 per blood vessel in the brain of 1,000 residents. That number is up compared to Riskesdas 2012 which amounted to 8.3 percent.

While the causes of stroke in the province of South Sulawesi were 3,986 cases (17.91\%). In Bulukumba Regency, based on reports from the stroke health service facilities, it has increased from year to year. In 2014, there were 426 reported stroke sufferers. Until now, stroke is the number one cause of death in various hospitals in Indonesia (Mahardika, 2016). Based on the records of the Hospital Medical Record $\mathrm{H}$. Andi Sulthan Daeng Radja Bulukumba in seruni and flamboyant treatment rooms in 2015 there were 319 cases of inpatient stroke, while in 2016 there were 430 inpatient stroke cases. In 2017, between January and March, there were 92 cases of stroke that were hospitalized. From the results of the researchers' initial observations regarding early mobilization in stroke patients, it was found that range of motion (ROM) training is needed to improve self-reliance, improve health, slow the process of entry of disease. The loss of ability to move in stroke patients in cervical care causes dependence and this requires nursing action namely range of motion (ROM) exercise therapy. Based on the 
facts and matters described above, the author is interested in examining "The Effect of Range of Motion Exercise (ROM) on the level of mobility of stroke patients in the seruni and flamboyant treatment room at H. Andi Sulthan Daeng Radja Bulukumba Hospital".

\section{MATERIAL AND METHODS}

This type of research is quantitative research, this type of research uses preexperimental research, with a one group pre and posttest design research design, because before being given treatment or therapy, the patient is examined first The level of mobility of stroke patients than after being given treatment or therapy then reviewed the level the mobility of stroke patients whether they change or not (Saryono and Anggraeni, 2013). According to Sugiono (2012), the population is a region of generalization consisting of objects/subjects that have certain qualities or characteristics determined by researchers to be studied which then concludes. As for the population in the study were all stroke patients in the Seruni and Flamboyant inpatients of H. Andi Sulthan Daeng Radja Hospital in Bulukumba, which amounted to 92 patients.

Sugiyono (2012) explains that the sample is part of the number and characteristics possessed by the population. The sample in this study amounted to 30 patients. This is based on suggestions given by Roscoe in (Sugiyono: 2012) that a decent sample size in research is between 30 to 500 .

Sampling using a non-probability sampling technique that is purposive sampling. Purposive sampling is a sampling technique that aims to be done not based on strata, groups, or random, but based on certain considerations/objectives. This technique is carried out on certain considerations such as time, cost, energy so that it cannot take large and distant samples (Saryono and Anggraeni, 2013). Research instruments are tools or facilities used by researchers in collecting data so that their work is easier and the results are better (careful, complete and systematic) so that it is more easily processed (Saryono and Anggraeni, 2013). The independent variable in this study is to provide passive range of motion (ROM) exercises to respondents twice a day for seven days and is carried out in the morning and evening, then observe muscle strength. while the Dependent variable is the level of stroke patient mobility measured using an observation sheet (mobility level) With the assessment criteria: Independent if the Patient can be independent / almost does not need help in meeting ADL, Partial dependence if the Patient needs the help of nurse/family in part in meeting ADL, and 
Total dependence if the patient needs the help of a nurse/family fully in meeting the $\mathrm{ADL}$ and requires a longer nurse/family time. The implementation of this treatment requires 30 minutes. The time-division consists of 5 minutes of informed consent, 5 minutes of observation before and after treatment, and 20 minutes of range of motion (ROM) training.

\section{RESULTS}

Table 1. Distribution of Number of Respondents by Gender, Age of Patient

\begin{tabular}{|c|c|c|}
\hline Gender & $\mathrm{n}$ & Persentage (\%) \\
\hline Male & 15 & 50 \\
\hline Female & 15 & 50 \\
\hline \multicolumn{3}{|l|}{ Age } \\
\hline 46- 55 Year & 13 & 43.3 \\
\hline 56-65 Year & 10 & 33.3 \\
\hline$>65$ Year & 7 & 23.3 \\
\hline Amount & 30 & 100 \\
\hline
\end{tabular}

Based on table 1 it can be seen from 30 respondents who were female as many as 15 people (50\%), while respondents who were male were 15 people (50\%). Based on table 5.2. It can be seen from the 30 most respondents, there were 13 respondents (aged 46-55 years old) (43.3\%), while at least respondents aged $>65$ years were 7 people (23.3\%).

Table 2. Distribution of Number of Respondents Based on the level of mobility of pre-intervention stroke patients

\begin{tabular}{lcc}
\hline \multicolumn{1}{c}{$\begin{array}{c}\text { The Level Of Mobility Of Stroke Patients Pre- } \\
\text { Intervention }\end{array}$} & n & Persentage (\%) \\
\hline \hline Total Dependency & 14 & 46.7 \\
Partial Dependence & 16 & 53.3 \\
\hline Amount & $\mathbf{3 0}$ & $\mathbf{1 0 0}$ \\
\hline
\end{tabular}

Based on table 2 in the results of this study of the 30 most respondents with the level of mobility of stroke patients before ROM were found in the partial dependency category of 16 respondents (53.3\%), and the level of mobility of stroke patients before ROM was performed at least in the dependency category a total of 14 respondents (46.7\%). 
Table 3 Distribution of Number of Respondents Based on the level of mobility of post-intervention stroke patients

\begin{tabular}{lcc}
\hline The Level Of Mobility Of Stroke Patients Post Intervention & $\mathbf{n}$ & Persentage (\%) \\
\hline \hline Total Dependency & 8 & 26.7 \\
Partial Dependence & 19 & 63.3 \\
Independent & 3 & 10.0 \\
\hline Amount & $\mathbf{3 0}$ & $\mathbf{1 0 0}$
\end{tabular}

Based on table 3 in the results of this study of the 30 number of respondents with the level of mobility of stroke patients after ROM was done most respondents were in the category of partial dependence of 19 respondents (63.3.3\%), while the level of mobility of stroke patients after being given ROM training was at least respondents were in the independent category of 3 respondents (10\%).

Table 4 Effects of range of motion (ROM) exercises on the level of mobility of stroke patients

\begin{tabular}{|c|c|c|c|c|c|c|c|c|c|}
\hline & & & est le & lof $\mathrm{m}$ & & & & \multirow{3}{*}{ Amount } & \multirow{3}{*}{$p$} \\
\hline & & \multicolumn{2}{|c|}{$\begin{array}{l}\text { Total } \\
\text { Dependency }\end{array}$} & \multicolumn{2}{|c|}{$\begin{array}{l}\text { Partial } \\
\text { Dependence }\end{array}$} & \multicolumn{2}{|c|}{$\begin{array}{c}\text { Indepen } \\
\text { dent }\end{array}$} & & \\
\hline & & $\mathrm{N}$ & $\%$ & $\mathrm{n}$ & $\%$ & $\mathrm{n}$ & $\%$ & & \\
\hline \multirow{2}{*}{$\begin{array}{c}\text { Pretest level } \\
\text { of mobility }\end{array}$} & $\begin{array}{c}\text { Total } \\
\text { Dependency }\end{array}$ & 7 & $\begin{array}{c}23 \\
3\end{array}$ & 7 & 23,3 & 0 & 0 & 14 & \multirow{3}{*}{0,007} \\
\hline & $\begin{array}{c}\text { Partial } \\
\text { Dependence }\end{array}$ & 1 & 3,4 & 12 & 40 & 3 & $\begin{array}{l}1 \\
0\end{array}$ & 16 & \\
\hline \multicolumn{2}{|c|}{ Amount } & 8 & 26,7 & 19 & 63,3 & 3 & 10 & 30 & \\
\hline
\end{tabular}

Based on table 4, it is known that respondents with total dependency mobility level before ROM technique are performed with total dependency mobility level after ROM technique done by 7 respondents (23.3\%), and who have partial dependency mobility level before ROM with partial dependency mobility level. ROM as many as 12 respondents (40\%), as well as those who had partial dependency mobility prior to ROM with independent mobility levels after ROM were performed before ROM did 3 respondents (10\%), while those with heavy workloads with emotional mental disorders were 7 respondents (20\%). The results of the analysis using Wilcoxon test obtained significance value of 0.007 ( $p<0.05$ ), it can be concluded that "there is the effect of 
range of motion (ROM) exercise on the level of mobility of stroke patients in the seruni and flamboyant ward of H. Andi Sulthan Daeng Hospital Radja Bulukumba. "

\section{DISCUSSION}

In the results of this study of the 30 most respondents, the most respondents with the level of mobility of stroke patients before ROM were found in the category of partial dependence as many as 16 respondents (53.3\%), and the level of mobility of stroke patients before ROM was carried out at least in the total dependency category of 14 respondents (46.7\%). This research is in line with the research conducted by Murtaqib (2013). The results of the study showed that the average angular ability of the joint flexion range before active ROM exercises was 125.27 degrees and the extension was 28.27 degrees. Based on these data shows that most stroke sufferers in Tanggul District before active ROM exercises have decreased the ability to perform a joint range of motion. The problems caused by stroke according to Irfan (2010) for human life are very complex. Disorders of vital brain functions such as coordination disorders,

impaired balance, impaired posture control, disturbance of sensation, and impaired motion reflexes will decrease the ability of the functional activities of individuals in everyday life.

Someone who has movement disorders or interference with muscle strength will have an impact on their daily activities. To prevent complications from other diseases it is necessary to do mobilization exercises. Mobilization is a person's ability to move freely, easily, and regularly which aims to meet the needs of a healthy life. Mobilization is needed to improve self-reliance, improve health, slow down the disease process, especially degenerative diseases and for self-actualization (self-esteem and body image (Mubarak, Lilis, Joko, 2015). Mobilization or rehabilitation exercises in stroke patients also aim to improve neurological function through physical therapy and other techniques. Early mobilization and rehabilitation in bed is a stroke rehabilitation program, especially for several days to weeks after a stroke. The aim is to prevent the occurrence of stiffness (contractures) and setback stiffness (deconditioning), optimize treatment in connection with medical problems and provide psychological assistance patients and their families (Junaidi, 2013).

Weak limb weakness in stroke is a common symptom, weakness is found in the form of weakness on the right or left side. Disturbances in the media cerebral arteries cause control of lateral hemiparesis more on the arms. These blockages often cause 
muscle weakness and controlateral spasticity and sensory deficits (hemianesthesia) due to damage to the lateral precentral gyrus and postcentral, in addition, apraxia of the left arm if the anterior colostrum and the relationship with the dominant hemisphere to the right motor cortex are disrupted. Hemiparesis results from a vascular lesion in the brainstem region of the side that shows features of alterations, namely the ipsilateral hemiparesis lesion, while the distal hemiparesis lesion is controlateral. Many nerve cells die during a stroke, areas of the brain that die cause physical and mental problems that are often experienced by stroke sufferers, but there are areas still alive but not active for a while after a stroke ie nerve cells in the penumbra, in the staging of the stroke the cells are sought potentially protected life.

Based on the researchers' assumptions that ROM aims to increase muscle strength, prevent bone demineralization and maintain muscle function, 75\% muscle strength, in addition, it aims to help the motor learning process, ROM can increase the range of joint motion both flexion and extension due to internal motivation in stroke patients because of internal motivation is an internal drive that arises does not require external stimulation because it already exists within the individual, in this study the existence of family support and motivation to help do ROM increases the expectations and levels of healing in patients. In the results of this study, out of 30 respondents with the mobility level of stroke patients after ROM, the majority of respondents were in the category of partial dependence as many as 19 respondents (63.3.3\%), while the level of mobility of stroke patients after ROM training was at least respondent found in the independent category is 3 respondents (10\%).

This study is in line with research conducted by Rahayu, (2014), it can be concluded that there is an effect of providing Range of Motion (ROM) training on motor skills in post-stroke patients at Gambiran Kediri Regional Hospital in 2014. Neurological symptoms that arise depend on severe blood vessel disorders and the location. Clinical manifestations of acute stroke can be in the form of changes in mental status, vision problems, aphasia, vertigo, nausea, vomiting, headaches and decreased motor function (Mansjoer, 2012). These changes affect the physical and mental structure (psychology). This study is in line with the research conducted by Murtaqib (2013). The results of the study showed that the average ability of the flexion and extension joints range after active ROM exercises had changed. Measurement of elbow joint range of motion in stroke patients flexibly after active ROM in each treatment group experienced an 
increase in the degree of angle of the elbow joint. The results of the study showed that $100 \%$ Klein had an increased range of elbow joint motion after an active range of motion exercises.

Miller (1995) suggested that one of the conditions that cause contractures is paralysis. Paralysis (paralysis) is one of the clinical symptoms caused by stroke. Paralysis is caused by loss of nerve supply to the muscles so the brain is unable to move the extremities, loss of nerve supply to the muscles will cause the muscles to no longer receive the contraction signals needed to maintain normal muscle size so that atrophy occurs. Muscle fibers will be damaged and replaced by fibrous tissue and fat tissue. Fibrous tissue that replaces muscle fibers during atrophy due to denervation has a tendency to continue to shorten for months, called contractures. Muscle atrophy causes decreased activity in the joints so that the joint loses synovial fluid and causes joint stiffness. Joint stiffness and a tendency for muscles to shorten cause a decrease in range of motion in the joint. Prevention and appropriate treatment in stroke patients is very important. Stroke that does not get good handling will cause various levels of disturbance, such as decreased muscle tone, loss of sensibility in some parts of the body, decreased ability to move diseased limbs and inability to perform certain activities. Stroke patients who experience weakness on one side of the body are caused by a decrease in muscle tone, so they are unable to move their body (immobilization). Immobilization that does not get proper treatment, will cause complications in the form of tone abnormalities, orthostatic hypotension, deep vein thrombosis.

Range of motion exercises are done to normalize again range of joint motion. Exercises that can be given to stroke sufferers, one of which is a range of motion exercises. Range of motion exercises are physical activities to improve health and maintain physical health. Someone who does exercise continuously will occur physiological changes in the body system such as lowering blood pressure, improving muscle tone, increasing joint mobilization and increasing muscle mass. These physiological changes are needed by stroke patients to prevent re-stroke and reduce contractures. The benefits of the range of motion, one of which can increase blood circulation which carries nutrients for cell survival, especially muscle cells that are useful for carrying out its activities, namely contraction and relaxation so as to minimize the occurrence of contractures. Muscle is a network that plays an important role in the motion system. 
According to the researchers' assumptions. ROM exercises are performed with the aim of maintaining or increasing muscle strength, maintaining joint mobility, stimulating blood circulation and preventing deformities. ROM is useful for determining the value of the ability of joints and muscles in doing the movement, assessing bones and joints, muscles, preventing joint stiffness and improving blood circulation. It can be seen that respondents who have total dependency mobility level before doing ROM technique with total dependency mobility level after ROM technique done by 7 respondents (23.3\%), and who have partial dependency mobility level before ROM with independent mobility level after ROM implementation. ROM as many as 3 respondents (10\%), whereas those with heavy workloads with emotional mental disorders were 7 respondents (20\%), Based on table 5.7, the results of the analysis using the Wilcoxon test obtained significance value of 0.007 ( $p<0.05)$, it can be concluded that "there is the effect of a range of motion (ROM) exercise on the level of stroke patient mobility in the serene and flamboyant hospital H . Andi Sulthan Daeng Radja Bulukumba ". Murtaqib (2017) research results show active ROM can increase changes in joint range of motion. Measurement of the angle of flexion range in the group performed active ROM exercises there was an increase or improvement in the angle of flexion range of 11.4 degrees. Statistical results obtained p-value of $0.001(\mathrm{p}<0.05)$ showed that there was a significant difference in the angle of flexion range before and after the practice of active ROM.

Based on the results of research conducted by Pradana (2016) that can be concluded the range of motion (ROM) action, treatment of bedsore and changing positions every 2 hours has proven effective to prevent muscle stiffness in stroke patients. Quickly and appropriately perform a range of motion or mobilization exercises can prevent complications. Stroke patients who experience weakness on one side of the body are caused by a decrease in muscle tone, so they are unable to move their body (immobilization). Immobilization that does not get proper treatment will cause complications in the form of tone abnormalities, orthostatic hypotension, deep vein thrombosis and contractures (Murtaqib, 2013).

Someone who has movement disorders or interference with muscle strength will have an impact on their daily activities. To prevent complications from other diseases it is necessary to do mobilization exercises. (Purwanti \& Purwaningsih, 2013). One form of mobilization that can be given is by doing ROM exercises. Muscle strength in stroke 
patients can be done immediately through ROM exercises after a stroke has passed. The impact of ROM exercises that are not immediately carried out in stroke patients as early as possible is the occurrence of muscle cell atrophy, joint stiffness, decreased muscle contraction, pain during movement and overall will result in the inability to move or activity (Murtaqib, 2013).

Range of motion (ROM) is done four to five times a day every 3 hours or more in cherry blades. Range of motion in the right limb is done by passive ROM because when doing exercises the movement must be assisted by a nurse or family, while for the left limb is done active ROM because the patient can still move his left limb. Range of motion is a joint movement exercise that allows contractions and muscle movements, where the client moves each joint according to normal movements both actively or passively. Both passive and active ROMs have an effect on motor function in upper limb members in post-stroke patients (Chaidir, Ilma, 2014). This passive range of motion is useful for maintaining the flexibility of muscles and joints by moving the muscles of others passively such as nurses lifting and moving the patient's legs, while the active range of motion is useful for exercising flexibility and

muscle and joint strength by actively using their muscles for example when the patient is lying down the patient move his own hands or feet without assistance (Mubarak, Lilis, Joko, 2015).

There are some basic principles in doing ROM exercises. ROM should be repeated about 8 times and done at least 2 times a day, ROM is done slowly and carefully so as not to tire the patient, in planning a ROM exercise program, pay attention to the patient's age, diagnosis, vital signs, and duration of bed rest (Sager, M., Sylvain G., 2014), ROM is often programmed by doctors and done by physiotherapists or nurses, body parts that can be done ROM are neck, fingers, arms, elbows, shoulders, heels, feet, and ankles, ROM can be done on all joints or only on the parts that are suspected of experiencing the disease process, doing ROM must be following the time, for example, after bathing or routine care has been carried out (Anderst, WJ, et al., 2013). According to the researchers' assumptions, the results of the study found that some respondents experienced a slight increase in the range of motion. This research uses active and passive range of motion exercises. Bandy and Bringgle said that a range of motion exercises can be done 1-3 times a day. Range of motion exercises in addition to increasing joint range of motion can also stimulate blood circulation, maintain muscle 
elasticity and reduce pain. Range of motion exercises can prevent a decrease in joint flexibility and joint stiffness. Passive range of motion exercises are also useful for maintaining the flexibility of the muscles and joints where the client moves each joint according to the movement. Both passive and active ROM have effects on motor function in upper limb members in post-stroke patients

\section{CONCLUSIONS}

There is an effect of range of motion (ROM) exercise on the level of mobility of stroke patients in the seruni and flamboyant care of H. Andi Sulthan Daeng Radja Bulukumba Hospital. Can add information and input for health workers in order to improve the quality of health services provided and is expected to also provide benefits to the public in terms of information about the importance of range of motion (ROM) training on the level of mobility of stroke patients

\section{REFERENCES}

Arikunto, S. (2010). Prosedur Penelitian Suatu Pendekatan Praktek. Rineka Cipta:Yogyakarta.

Artati, Yuni. (2013). Hasil Penelitian Pengaruh Mobilisasi Dini Pada Pasien Stroke Infark Terhadap Peningkatan Pemulihan Fungsional.

Asmadi, (2011). Teknik Prosedural Keperawatan: Konsep dan Aplikasi Kebutuhan Dasar Klien. Jakarta: Salemba Medika

Aspuah, Siti. (2013). Kumpulan Kuesioner dan Instrument Penelitian Kesehatan. Nuha Medika: Yogyakarta.

Buku Panduan Penyusunan Karya Ilmiah (SKRIPSI) Program Studi S1 Keparawatan STIKES Panrita Husada Bulukumba 2016

Dharma, K. (2011). Metodologi penelitian keperawatan, Trans Info Media: Jakarta

Hernawati, Ika Yussi. (2009). Hasil Skripsi Penatalaksanaan Terapi Latihan Pada Pasien Paska Stroke Hemorage Dextra Stadium Recovery. Universitas Muhammadiyah Surakarta.

Jumraini. 2013. Stroke dan Pencegahannya. Identitas Universitas Hasanuddin. Makassar

Kozier, et.al. (2011). Buku Ajar Fundamental Keperawatan: Konsep, Proses, Dan Praktik. EGC: Jakarta. 
Lestari, T. (2015). Kumpulan Teori Untuk Kajian Pustaka Penelitian Kesehatan, Nuha Medika: Sorowajan Baru, Yogyakarta

Lingga, Lani. 2013. All About Stroke. Kelompok Gramedia. Jakarta

Mahardika, Pradana. (2016). Hasil Penelitian Upaya Peningkatan Mobilitas Fisik Pada Pasien Stroke Nonhemoragik Di Rsud Dr. Soehadi Prijonegoro: Fakultas Ilmu Kesehatan Universitas Muhammadiyah Surakarta.

Maulana, Nova. 2014. Sosiologi \& Antropologi Kesehatan. Nuha Medika. Yogyakarta

Murtaqib. (2013). Hasil Penelitian Pengaruh Latihan Range Of Motion (Rom) Aktif Terhadap Perubahan Rentang Gerak Sendi Pada Penderita Stroke Di Kecamatan Tanggul Kabupaten Jember: Jurnal Ikesma Volume 9 Nomor 2 September

Nursalam, (2011). Metodologi Penelitian Ilmu Keerawatan Pendekatan Praktis. Salemba Medika: Jakarta

Notoatmodjo, S. (2010). Metodologi penelitian kesehatan, Rineka Cipta: Jakarta

Pradana Mahardika Dodya. (2016). Hasil Skripsi Upaya Peningkatan Mobilitas Fisik Pada Pasien Stroke Nonhemoragik Di Rsud Dr. Soehadi Prijonegoro. Universitas Muhammadiyah Surakarta

Prastya, Andy. (2013). Hasil Penelitian Pengaruh Mobilisasi Miring Kanan Miring Kiri Terhadap Pencegahan Konstipasi Pada Pasien Stroke Infark Dengan Tirah Baring Lama Di Ruang Icu Rsud Prof. Dr. Soekandar Mojokerto. Sekolah Tinggi Ilmu Kesehatan Majapahit Mojokerto.

Potter \& Perry. (2012). Buku ajar fundamental keperawatan: konsep, proses, dan praktik. Ed-4. Jakarta: EGC.

Pudiastuti, Ratna Dewi. 2011. Penyakit Pemicu Stroke. Nuha Medika. Yogyakarta

Purwanti Ririn \& Purwaningsih Wahyu. (2013). Hasil Penelitian Pengaruh Latihan Range Of Motion (Rom) Aktif Terhadap Kekuatan Otot Pada Pasien Post Operasi Fraktur Humerus Di Rsud Dr. Moewardi. Gaster Vol. 10 No. 2 Agustus.

Rahayu, Ika Nur. (2015). Hasil Penelitian Pengaruh Pemberian Latihan Range Of Motion (Rom) Terhadap Kemampuan Motorik Pada Pasien Post Stroke Di Rsud Gambiran: Jurnal Keperawatan, Volume 6, Nomor 2 Juli 2015: 102 107

Rustianawati Yuni, Et.Al., (2013). Hasil Penelitian Efektivitas Ambulasi Dini Terhadap Penurunan Intensitas Nyeri Pada Pasien Post Operasi Laparatomi Di Rsud Kudus: Jikk Vol. 4, No 2, Juli : 1-8 5 
Saryono \& Anggraeni, MP. (2013). Metodologi Penelitian Kualitatif dan Dalam Bidang Kesehatan. Nuha Medika: Jakarta.

Saryono. (2011). Metodologi penelitian keperawatan. UNSOED: Purwokerto.

Setyadi Imam Masykuri. (2014). Hasil Skripsi Kajian Asuhan Keperawatan Pasien Dengan Gangguan Mobilisasi Pada Penyakit Stroke Non Hemoragik Di Rsud Dr. Moewardi. Stikes Pku Muhammadiyah Surakarta

Sopiyuddin, Dahlan. (2010). Besar Sampel dan Cara Pengambilan Sampel Dalam Penelitian Kesehatan dan Kedokteran. Salemba Medika: Jakarta.

Sugiyono. (2012). Metode penelitian kuantitaif, kualitatif dan R\&D. Alfabeta: Bandung

Syamsuddin, et al. (2015). Pedoman praktis metodologi penelitian internal (pendekatan kualitatif, kuantitatif, pengembangan dan mix-method) Wade Group: Indonesia 